\title{
FISHING LURES, A HAZARD TO SEA BIRDS
}

by R. Wayne Campbell, Burnaby, B.C.

Each year, especially during the usy summer months, many sea birds re accidentally caught or "hooked" $y$ sports fishermen along the B.C. oast. Glaucous-winged Gulls (Larus laucescens) and Marbled Murrelets Brachyramphus marmoratum) are he two sea birds most consistently aught, though occasionally Pigeon Guillemots (Cepphus columba) and ommon Murres (Uria aalge) are inolved.

While working with the B.C. Parks Banch on Mitlenatch Island Nature ark (see Blue Jay, December, 1965) luring the summers of 1964, 1965 and 1966 I heard many disgruntled fishermen complain of their catches of "feathers" instead of "scales". I quesioned many of them and compiled the lollowing notes from their reports.

The Glaucous-winged Gull, B.C.'s most abundant resident gull, is usually faught on silver "flashers" which are rolled in a boat's wake just beneath the surface of the water. Sometimes the flasher is baited with strips of herring. To the hungry gull, which is primarily a surface feeder, the dartng, shiny flasher must closely resemble a fish. In one passing swoop the bird engulfs the "fish" and before it fully realizes its mistake, the fishhooks have become embedded in the ining of the esophagus. In attempts to struggle free the gull may snap the fish-line and depart with an embedded ure from which a lengthy piece of the line usually dangles. In time this bird will probably die from starvation. If, by some chance, the bird is able to feed it seems likely that the dangling fish-line will become entangled in beach debris such as logs and small bushes. Probably a combination of hemorraging and starvation soon accounts for the bird's death.

Occasionally fishermen reel in gulls that they accidentally catch, only to become frustrated by the problem of releasing the bird. Many fishermen

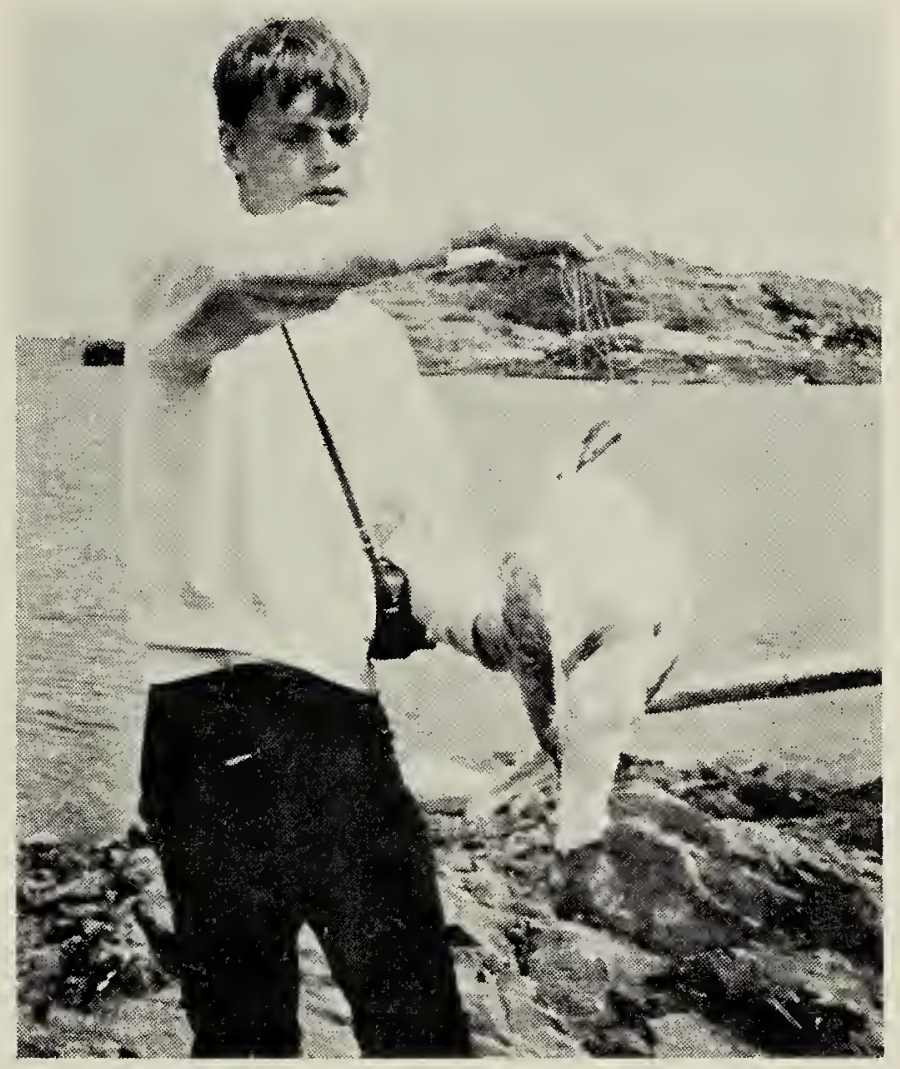

Adult Glaucous - winged Gull found dead on Mitlenatch Island by Barry Edwards. A fish hook was embedded in its esophagus.

are simply content to cut the line and let the gull fly off. Needless to say, the bird's chance for surviving is greatly reduced. Usually, with a little patience and common sense, the embedded hooks can be removed with a pair of needle-nosed pliers. The gull can then be released relatively unharmed.

Sometimes gulls misjudge the flasher and become entangled in the transparent fish-line. This, of course, is not as serious as being hooked. Usually the bird's flight is impaired and the fisherman can easily capture the gull and remove the entangled line. A note of caution: gulls can inflict painful cuts with their strong bills. Captured birds can easily be calmed down by covering their head with a stocking or shirt sleeve.

Marbled Murrelets, small, darkbrown, chubby-bodied sea birds, feed primarily on fish which they pursue by diving, sometimes to considerable depths. This bird is frequently caught 
in deep water on small, brilliantly colored plugs, such as a "Lucky Louie" or a "Rexfield". Usually the Murrelet is only hooked by the bill and the plug, therefore, can be easily removed. Last summer, one fisherman reported catching a Marbled Murrelet at a depth of about 75 feet.

In years to come, sea birds will undoubtedly continue to be caught by sports fishermen. Mortalities resulting from these accidents can be reduced considerably if fishermen will make an effort to detach embedded lures and to untangle fish-lines from captured birds.

Most sports fishermen do not realize that many sea birds are indirectly beneficial to man. If it weren't for the Glaucous-winged Gulls which keep commercial and public oyster beds void of predating starfish there would be few oysters on the Pacific Coast. Our litter-free beaches and shorelines owe their cleanliness to an army of scavenging sea birds. Also, many sea birds signal good fishing spots, by congregating to feed on schools of small fish which in turn the salmon feeds on.

Sea birds are a valuable and exciting addition to British Columbia's avifauna and certainly deserve humane treatment.

\section{COMMENSAL FEEDING OF GULL AND PEREGRINE}

by Errol Anderson, 3520 W. 13th Ave., Vancouver, B.C.

February 18, 1967 was an especially rewarding day for birding on. Sea and Iona islands near Vancouver. Lowell Orcutt and myself, members of the Vancouver Natural History Society's Intermediates, recorded 60 species for the day, including Horned Larks, Snow Geese, Black - bellied Plover, Ruddy Ducks, and early migrating Savannah Sparrows. We spotted four male European Widgeon and one female among the several thousand American Widgeon, Green - winged Teal, Pintail, and Shoveler in the flooded fields on Sea Island. Six Rough-legged Hawks and four Marsh Hawks were seen in the short space of three acres near the airport. A total of six Snowy Owls and 15 Short-eared Owls were in the area. A hen Redhead was preening herself along with the Canvasback and Lesser Scaup on the fenced-in pond at Iona Island. We were also rewarded with a glimpse of an elusive Gray Partridge as it flushed from the low brush near the airport.

The highlight of the day, however, was not any of these unusual sightings but a gull standing in the middle of a field. Gulls have an unusual fascination for me, so I set up my telescope for a closer look. I noted that it was a Herring Gull in breeding plumage, but what was unusual was a male Peregrine Falcon eating a duck less than a foot away! The gull was clearly waiting patiently for the table scraps. At our loud exclamations of astonishment the Peregrine picked up his meal and flew to the next field with the gull hotly in pursuit.

I have heard of gulls waiting at the paws of Alaska Brown Bears as they hook salmon from the cascading rivers of the north and I have seen pictures of the Arctic Fox tarrying on the heels of the Polar Bear for the remnant of the seal kill, but I have never heard of a gull and Peregrine commensal feeding association. This is a type of feeding where one of the two animals is the host and the other is the boarder. 